Lire Journal: Journal of Linguistics and Literature Volume 2 Number I March 2018

\title{
NATIONAL ROMANTIGISM IN WALT WHITMAN POEMS
}

\author{
Tomi Arianto \\ Universitas Putra Batam \\ tomy2088.ta@gmail.com \\ Batam, Indonesia
}

\begin{abstract}
Romanticism is often misunderstood as something genuine love and merely about romance. In fact, romanticism is an understanding of great ideas that also be delivered great ideas. The development of Romanticism delivered a new orientation that called National Romanticism by maintaining the freedom of individual, sovereignty, and independent of human rights. This study took data from three Walt Whitman poems; Patriotic, War Democracy, and Poem of America. Researcher was using the concept of interpretation to explore the meaning of poetry and the influence of romanticism in Whitman poetry. Researchers use Isaiah's theory in his book "the root of romanticism" to explore the influence of the romanticism idea on Whitman's poems. From the three samples of poetry, it is found that romanticism is very influential in Whitman poetry, especially the idea of romantic nationalism. Patriotic themes, nationalities and egalitarian concepts are reflected in Whitman's collection of "Leaves of grass" poems. Patriotic themes and nationalities are seen from the struggle for the right of individual freedom in opposing slavery and aristocratic government. The egalitarian concept is seen from the struggle to promote equality, as well as the democracy system that promotes people's sovereignty. The role of the idea of romanticism has evolved in American territory because it shares the same pattern and state of affairs as revolutions against noble, social, and political norms and rationalization of nature. Thus, the representation of romantic ideas originating from Western Europe of the 18th century has penetrated into the 19th century America which is reflected in the works that carried Whitman.
\end{abstract}

\section{Keywords: Romanticsm, Poems, Walt Withman}

\section{INTRODUCTION}

Romanticism is a movement of art, literature, and intellectual originating from Western Europe in the 18th century during the Industrial revolution. The Romantic Movement is partly a revolution against the norms, social, and political norms of the period of enlighten and reaction to the rationalization of nature. There are several characteristics of the Romantic era among such as; back to Nature, moodiness, pessimism, sentimentalism, individualism, and also exoticism. The Movement of Romanticism was spearheaded by a great philosopher named Jean-Jacques Rousseau (1712-1728) with his famous expression "man is born free, and everywhere he is chained" (Isaiah, 1999). In later developments, Rousseau then made through his writings "The social contract" which promotes a free, happy, and humane society based on human nature. Therefore, human beings must form fellowship to preserve the original state by being obedient to itself or independent. Thus, freedom itself can be a part of forming a state, the sovereignty of the people by continuing to promote individual freedom. This makes Rousseau a prominent figure of democracy who later became an inspiration in the spirit of Nationalism.

Nationalism and Romanticism have sustained relationships as already mentioned in the preceding paragraph. The development of Romanticism was growing a new orientation called National Romance by maintaining the freedom of individual, happiness, and free human rights. As Fichte and Schiller's ideas are recognized as "the restrained of Romanticism" (Isaiah, 1999). With his thoughts on freedom, the idea of will, liberty, autonomy, then appears a nationalist and patriotic spirit for German 
society. In the root of Romanticism Isaiah said that:

"Fichte began by talking about individuals, then he asked if himself what an individual was, how one could become a perfectly free individual... Spirit for Fichte is not the spirit of an individual man, but something which is common to many men, and it is common to many men because each individual spirit is imperfect,.... So, gradually, he moved from the notion of the individual as an empirical human being in space to the notion of the individual as something larger, say a nation, say a class, say a sect. Once you move to that, then it becomes its business to act, it becomes its business to be free, and for a nation to be free means to be free of other nations, and if other nations obstruct it, it must make war."(Isaiah, 1999)

From the quotations above give an overview of how Fichte views individual freedom and individual spirit. He argued that individual liberty and spirituality would be stronger if an individual could move on to something larger like a nation, a sect, and a class. As the Fichte analogy "language was not invented by me, it was invented by others, and $\mathrm{i}$ am part of some common stream in which I am an element". In other words, the spirit of nationality, class or even the smallest of sects does not release the individual freedom which is one element that is taken into account in the wider spirit but makes it more perfect and stronger. This idea also addresses the relationship between Nationalism and Romanticism. The romanticism that carries the themes of nature, freedom, individualism, further uniqueness can also lead to a larger scope of the spirit of nationalism or nationalism while remaining based on the individual's sovereignty, freedom, and the uniqueness of the elements present in the nationality.

The ideas of National Romance have also influenced literary works in America, one of which is contained in the themes of poetry raised by Walt Whitman. Walt Whitman is an American-Dutch bloody poet. He was born in West Hill, Long Island on May 31, 1819 and died in Camden, Philadephia on May 26, 1892. He published his own work containing 12 rhymes with the title Leaves of grass. Whitman is more interested in developing free genre works, not following the conventional tradition of literature. Whitman's works are strongly influenced and contain elements of Romanticism. He praised the erotic love story, the boldness of human struggle, democracy and equality, and reveals an almost mystical, patriotic and patriotic American identity, and is concerned with what will be the researcher discussed in this paper on Elements of National Romanticism contained in the poem of Poetry Walt Whitman(Ed Folsom and Kenneth M. Price, 2017). There are four themes relating to Romantic Nationalism which will be discussed in the discussion section; Patriotic, War, Democracy, and Poem of America. The researcher chose each of Whitman's poems in each of these themes that represent to see the correlation / historical of his time, related to the ideology of the author, as well as his relationship with the characteristic of Romantic Nationalism.

\section{DISCUSSION}

1.1.Patriotic dalam Puisi Beat! Beat! Drums, Walt Whitman (1865)

BEAT! BEAT! DRUMS!

Beat! beat! drums!—blow! bugles!

blow! Through the windows- 
through doors-burst like a ruthless force, Into the solemn church, and scatter the congregation, Into the school where the scholar is studying; Leave not the bridegroom quiet-no happiness must he have now with his bride, Not the peaceful farmer any peace, ploughing his field or gathering his grain, So fierce you whirr and pound you drums-so shrill you bugles blow.

Beat! beat! drums!—blow! bugles! blow! Over the traffic of cities-over the rumble of wheels in the streets; Are beds prepared for sleepers at night in the houses? no sleepers must sleep in those beds, No bargainers' bargains by day-no brokers or speculators-would they continue? Would the talkers be talking? would the singer attempt to sing? Would the lawyer rise in the court to state his case before the judge? Then rattle quicker, heavier drums-you bugles wilder blow. Beat! beat! drums!—blow! bugles! blow! Make no parley—stop for no expostulation, Mind not the timidmind not the weeper or prayer, Mind not the old man beseeching the young man, Let not the child's voice be heard, nor the mother's entreaties, Make even the trestles to shake the dead where they lie awaiting the hearses, So strong you thump O terrible drums-so loud you bugles blow. (Whitman in Warner, 2004)

This poem was made in 1865 , there are many of Walt Whitman's poems in this Patriotic-themed (1865-1866) period. One of them is Beat poetry! Beat! Drum!. This poem has 3 stanzas and consists of 7 lines starting with the repetition "Beat! Beat!
Drums! -blow! Bugles! Blow!" in every stanza. Repetition of the syllable mimic if read in rhythm will resemble the sound of drums and trumpets that are usually sung to accompany the soldiers. Whitman uses Drums and trumpets as a symbol of warfare. This is also related to the historical conditions at the time when the American Civil War was going on from 1861 to 1865 . If you look at the history of American War is due to the struggle and struggle to eliminate slavery in the United States. 11 slave states in southern America declare a separation from the United States that resulted in a 4year battle and consumed more than 600,000 lives (Chamber, 1999).

This poem also contains elements of National Romance which are related to Romanticism discussed in the introduction. The first of the themes used in connection with the Civil War as the symbol of the Drum and the trumpet sounds about the element of Patriotism that is identical with Nationalism. Typical Romantic in Patriotic theme is related and based on the individual's struggle to escape from the form of slavery. As the idea of individualism Fitche in Isaiah (1999) we moved from the notion of the individual as an empirical human being in space to the notion of the individual as something larger. Thus the patriotic spirit of nationality here is a fixed movement based on awareness of individual freedom. Whitman in this poem drummed of patriotic spirit is not only focused on the army, but also the spirit of war against slavery more in each individual. It is reflected from the choice of words, through the windows-through doors-burst like a ruthless force, into the solemn church, and scatters the congregation, into the school where the scholar is studying (Whitman in Warner, 2004). This quote shows Whitman's provocation of freedom aimed at all circles 
whether it be churches, congregations or associations of people, schools, and all that every individual has the right to freedom. Next verse "Leave not the bridegroom quietno happiness must have his field or gathering his grain, So fierce you whirr and pound you drums-so shrill you bugles blow" show no freedom if still in bondage. In this case, Whitman called for the struggle and left the comfort behind slavery "bridegroom quiet" for the students, "plowing his field or gathering his grain" for the farmers hinted at the appeal to all individuals who crave freedom. "Shrill you bugles blow" as a call to unite voice the freedom(Hroch, 2007).

Likewise with the second stanza in this poem, the battle of war and patriotism was also conveyed against "Over the traffic of cities-over the rumble of wheels in the streets" which refers to all circles even on the streets where everyone is on the streets; old, young, as well as various professions and jobs are called for "rattle quicker, heavier drums". This appeal to oppose the absence of diplomatic martyrdom from the ruler as quoted "would the talkers be talking? would the singer attempt to sing? Would the lawyer rise in the court to state his case before the judge?". It also again shows the element of National Romanticism in poetry that puts the freedom of the people, individuals, and nations to oppose the dictatorship of the ruler.

The third stanza is also increasingly asserted the unity to fight for individual freedom from the dictatorship of the sovereignty. Excerpt "Make no parley-stop for no expostulation, Mind not the timid" shows a Whitman's call to dare to speak out. The word "no parley" refers to a pessimistic attitude towards a government that has diplomatic ruling so do not necessarily believe in the excuse of deliberation. "No expostulation" is also an appeal not to be easily deceived by persuasion. Furthermore, the words "not the timid" as a call for the people do not to be afraid to speak up for freedom. Until the last line Whitman insists on the united call of fighting over freedom through quotations "So strong you thump $\mathrm{O}$ terrible drums-so loud you bugle blow".

From the analysis of Whitman's poem above, it is clear how the characteristics of National Romanticism which is very instrumental in the themed of Patriotism. The War's call to fight for freedom is not directed to the army but rather to the collective individuals of the American people. This also corresponds to the issue raised during that period of civil war in America which was based on the struggle to escape from slavery.

1.2. Poem of War dalam an Army Corps on the March Walt Whitman

\section{An Army Corps on the March.}

With its cloud of skirmishers in advance,

With now the sound of a single shot snapping like a whip,

and now an irregular volley,

The swarming ranks press on and on, the dense brigades

press on, Glittering dimly, toiling under the sun-the dust-cover'd men, In columns rise and fall to the undulations of the ground, With artillery interspers'd-the wheels rumble, the horses sweat,

As the army corps advances.

(Whitman in Warner, 2004)

The poem above is one of many of Whitman's poems about the Civil War in America. Of the many themes of poetry on civil war, "An Army Corps on the March" was 
selected in this analysis to show a variation of Whitman's poetry that not only inflames Patriotism or the struggle for freedom but also the condition of the soldier of American civil war. Although clearly the element of Nationalism is not openly mentioned in poetry but if further analyzed the issues raised in this poem still talk about the more romantic side of Romantic nationalism towards individuals / people who are the soldier members of American civil war.

From the title, it could be guessed what the poem talked about. "An Army Corps on the March" written in 1865 is still associated with the turmoil of the American civil war. Whitman in this poem is more emphasis on the conditions of soldiers joining in a civil war whose goal to escape from slavery. The background of volunteer soldier recruitment in civil war is visible from the following quotations:

About 2.75 million soldiers fought in the Civil War -2 million for the North and 750,000 for the South. According to historian Bell I. Wiley, who pioneered the study of the Civil War common soldier, the average Yank or Reb was a 'white, nativeborn, farmer, protestant, single, between 18 and 29.' He stood about 5 feet 8 inches tall and weighed about 143 pounds. Most soldiers were between the ages of 18 and 39 with an average age just under 26 Men on both sides were inspired to fight by patriotism, state pride, the chance for adventure, steady pay. Union soldiers fought to preserve the Union; the common Confederate fought to defend his home. Later in the war, increasing numbers of Federal soldiers fought to abolish slavery, if for no other reason than to end the war quickly. (historynet, 2014)

The quotation above indicates that the soldier volunteer of American civil war consists of various races, colors, ages, and religions whose purpose is to fight for freedom as an independent individual and free from the form of slavery. Whitman raised the Poet that talks about the conditions of soldiers during wartime also to show the spirit of nationalists and patriotic individuals who are members of the army in fighting for freedom. In the first and second line; "with its cloud of skirmishers in advance, with now the sound of a single shot snapping like a whip and now" an irregular volley in poetic Whitman language illustrates the courage of soldiers in the war where they never abstain back in the face of bullet strikes. The third line also gives an idea of the struggle of troops fighting in the war. "With artillery interspersed-the wheels rumble, the horses sweat" on the sixth line, this Whitman deliberately chose the descriptions of artery soldiers who went down the war with non-soldiers with sophisticated equipment. This shows that Whitman poem raises the courage of individual volunteer soldiers who are fighting for freedom.

The element of Nationalist Romanticism in this poem also clearly influences Whitman's thinking. The poem that raised the courage of the army volunteers in the civil war suggests that Whitman continues to uphold nationalist themes in his poetry that still puts individual freedom as main point. Individual freedom here is in order to escape the form of slavery and dictatorship. The individual's freedom then bring forth to a collective force as a united army volunteer to defend his territory, his family, and his independence. 
1.3.Poem of Democracy dalam puisi For You O Democracy, Walt Wiltman (1866)

\section{For You O Democracy.}

Come, I will make the continent indissoluble,

I will make the most splendid race

the sun ever shone upon,

I will make divine magnetic lands,

With the love of comrades,

With the life-long love of comrades.

I will plant companionship thick as

trees along all the rivers

of America, and along the shores of

the great lakes, and

all over the prairies,

I will make inseparable cities with

their arms about each

other's necks,

By the love of comrades,

By the manly love of comrades.

For you these from me, $\mathrm{O}$

Democracy, to serve you ma

femme!

For you, for you I am trilling these songs.

Etymologically, democracy comes

from the Greek word of demos (people), Kratos / kratein (government).A very wellrespected popular figure in Whitman's poems that raised the idea of democracy in America is Abraham Lincoln. According to Lincoln, democracy is a government of the people, by the people, and for the people (Kurniawan, 2015). The people become the determinant in government policy. They can give their opinions and voice directly in the democratic system. Lincoln is also a very prominent figure in the struggle for democracy in America and emancipation in the passage of anti-slavery legislation.

The "For You O Democracy" poem was written by whitman in the 1860s where there was a feud between North and South America where the southern states demanded secession and freedom from the slavery system. The Democracy Idea of Whitman's poetry is certainly related to the issue of the struggle of Lincoln and the activists who fought for a Democratic system based on People's sovereignty. Relating to the Characteristics of National Romance, Whitman's poetry on Democracy is also inseparable from that element. Democracy that holds the sovereignty of the people is also a facility of recognition of the rights and freedoms of individuals in voicing, expressing opinions, and acting. The democracy system based on Whitman is the most ideal system for resolving conflicts in America without the need for further divisions and bloodshed.

An ideal picture of the Democratic system in Whitman's poem is already visible from the first line "Come, I will make the continent indissoluble. Concept of Indissoluble" which was appointed by Whitman is not merely a unity of group fanaticism but a unifying idea that promotes individual rights as the basic concept of a democratic system. The ideal picture of unification by word; "magnetic lands", "comrades", and "make inseparable cities with their arms" are the result of a democratic system run in the ideas of Whitman thought. The eleventh line quotation, "For you these from me, $\mathrm{O}$ Democracy, to serve you ma femme", whereby Whitman uses Democracy "to serve ma femme" further clarifies the concept of nationalism that continues to promote the voice and sovereignty of individuals symbolized in a family.

From the description above, the characteristics of National Romanticism is clearly stated in Walt Whitman's poem "For You O democracy". The concept of Democracy coveted by Walt Whitman as an ideal system is egalitarian and put all human 
beings equal. Democracy that carries the concept of government from the people, by the people, and for the people put the people as individuals who are sovereign. This concept is in line with the thought of the romantic nationalism development that carries individual freedom in the spirit of national consciousness.

\section{CONCLUSION}

The development of Romanticism gave big influence to a new orientation called National Romanticism by maintaining the freedom of individual and free, sovereign, and independent human rights. The spirit of nationalism that is influenced by the concept of Romanticism has its own distinctively individual consciousness that is collective which then forms patriotic values, egalitarian, and even supports the concept of democracy. Walt Whitman's poem is heavily influenced by elements of National Romanticism. Patriotic themes and nationality champion the right of individual freedom in opposing slavery and aristocratic government. The egalitarian concepts of equality, as well as the Democratic system of promoting popular sovereignty are reflected in the Leaves of grass Walt Whitman's poems. Of course, these themes have a relationship with the characteristics of Romanticism that first developed in Europe. Does not rule out the possibility, the influence of National Romanticism is developed in various regions because it has the same pattern and the same situation as the revolution against the noble, social, and political norms of the period of enlighten and reaction to the rationalization of nature. Thus, the influence of Romanticism in other movements from culture, art, literature, and politics has a great role in subsequent periods.

\section{REFERENCES}

Chamber. (1999). Sejarah Perang sipil di Amerika Serikat.

Ed Folsom \& Kenneth M. P. (2017). The Walt Whitman Archive,. Retrieved May 30, 2018, from https://whitmanarchive.org/

historynet. (2014). American Civil war. Retrieved from Http://www.historynet.com/civil-war

Hroch, M. (2007). The Formation of National Romanticism Movement. Discourses of collective identity in central and southeast europe (1770-1945) Texts and commentaries. Volume II. National Romanticism -the formation of national movements. New York: Central European University Press.

Isaiah, B. (1999). The Roots of Romanticism. New Jersey: Princeton University Press.

Kurniawan, G. (2015). Kebebasan Sebagai Hakekat Demokrasi.Novatif, VIII(2), 95-114. Retrieved from file:///C:/Users/user/Downloads/2195-Article Text-4327-1-10-20150315.pdf

Warner, M. (2004). The Portable Walt Whitman. London: Pinguin Books. Ltd. 